\title{
Myocardial stereology in captive Callithrix kuhlii (Callitrichidae, Primates): healthy animals versus animals affected by wasting marmoset syndrome (WMS) ${ }^{1}$
}

\author{
Thalita A. Pissinatti ${ }^{2}$, Alcides Pissinatti ${ }^{3,4}$ and Carlos H. Freitas Burity ${ }^{5 *}$
}

\begin{abstract}
Pissinatti T.A., Pissinatti A. \& Burity C.H.F. 2007. Myocardial stereology in captive Callithrix kuhlii (Callitrichidae, Primates): healthy animals versus animals affected by wasting marmoset syndrome (WMS). Pesquisa Veterinária Brasileira 27(2):75-79. Setor de Morfologia, IBC, Universidade do Grande Rio (Unigranrio), Rua Prof. José de Souza Herdy 1160, uque de Caxias, RJ 25071-202, Brazil. E-mail: cburity@unigranrio.com.br

This study comprised 12 hearts of Wied's black-tufted-ear marmoset, Callithrix kuhlii (Coimbra-Filho 1985), 6 with Wasting Marmoset Syndrome (WMS) and 6 non-affected. Biometry was performed after death. After necropsy, the hearts were weighed, dissected, fixed in $10 \%$ formalin solution ( $\mathrm{pH} 7.2$ ), and processed for optical microscopy at $5 \mu \mathrm{m}$ sections stained with Haematoxylin-Eosin. Quantitative analysis was performed by stereological techniques. The statistical differences between the biometrical and stereological parameters were assessed by the Mann-Whitney test. The morphometric results showed that WMS causes a significant reduction in body and cardiac weights, and also in the volume density of vessels in those animals. Further studies are necessary to understand some of the results shown here.
\end{abstract}

INDEX TERMS: Wasting marmoset syndrome, myocardium, stereology, Callithrix, Callitrichidae.

RESUMO.- [Estereologia do músculo cardíaco em Callitrhix kuhlii cativos (Primatas, Callithrichidae): animais sadios versus animais afetados pela síndrome do emagrecimento progressivo (SEP).] Neste estudo, foram utilizados corações de 12 Sagui-de-Wied, Callitrhix kuhlii (Coimbra-Filho 1985), sendo 6 animais afetados pela SEP e 6 animais normais. Após a morte foi realizada a biometria seguida de necropsia. Os corações foram fixados em formol tamponado a $10 \%$, pesados e dissecados, sendo processados através de técnicas histológicas de rotina para microscopia óptica em cortes de $5 \mu \mathrm{m}$ corados por Hematoxilina-Eosina. As análises quantita-

\footnotetext{
${ }^{1}$ Received on October 31, 2006.

Accepted for publication on January 5, 2007.

2 Faculdade de Medicina Veterinária, Centro Universitário Plínio Leite (UNIPLI), Estrada do Cabuçu s/n, Caluge, Itaboraí, RJ 24.800-000, Brasil.

${ }^{3}$ Centro de Primatologia do Rio de Janeiro (CPRJ-FEEMA), Rua Pereira da Silva 25, sala 902, Niterói, RJ 24220-030, Brasil. Rua Fonseca Telles 121, São Cristóvão, RJ 20940-200, Brasil.

${ }^{4}$ Fundação Educacional da Serra dos Órgãos (FESO), Rua Pereira da Silva 25, sala 902, Niterói, RJ 24220-030, Brasil. Av. Alberto Torres 111, Alto, Teresópolis, RJ 25964-004, Brasil.

${ }^{5}$ Setor de Morfologia, IBC, Universidade do Grande Rio (Unigranrio), Rua Prof. José de Souza Herdy 1160, Bairro 25 de Agosto, Duque de Caxias, RJ 25071-202, Brasil. "Corresponding author: cburity@unigranrio.com.br
}

tivas foram feitas com o uso de técnicas estereológicas. As diferenças estatísticas entre os parâmetros biométricos e estereológicos foram avaliadas usando o test Mann-Whitney. Os resultados encontrados através da morfometria mostraram que a SEP causa uma redução significante do peso tanto corporal quanto do músculo cardíaco, e também uma redução no volume dos vasos nestes animais. Novos estudos são necessários para entender alguns dos resultados mostrados aqui.

TERMOS DE INDEXAC̄̃̃O: Síndrome do emagrecimento progressivo, miocárdio, estereologia, Callithrix, Callitrichidae.

\section{INTRODUCTION}

Brazil has the greatest number of species of nonhuman primates on the planet; however, many of these species are currently endangered by constant deforestation and traffic of the animals. One of these species is Callithrix kuhlii, Wied's black-tufted-ear marmoset (Coimbra-Filho 1985). In 1981, the kuhlii taxon was established for the southern region of Bahia, eastern Brazil, as a subspecies of Callithrix penicillata. This was not in accordance with had been established by other authors, who considered Callithrix kuhlii as a hybrid between Callithrix penicillata and C. geoffroyi (Rylands et al. 1993). In the past, an extensive area of the Atlantic Forest was the habitat for those 
animals; nowadays, however, they can only be found in a small area of the southeastern Bahia and in captivity in several places worldwide (Coimbra-Filho 1985). In the Atlantic Forest, they may be found in the canopy layer and may also reach the ground to feed on insects. The diet of the Callitrichidae consists basically of fruits, insects, and of plant secretions (Rylands et al. 1993).

The species lives in groups. The alpha animals, the first couple that mates, originate such groups, which may be comprised of up to 10 members. The offspring, after becoming adults, usually abandon the group to form other groups in new territories (Haig 1999).

The species is characterized by the dark brown color of its fur, with reddish-brown areas mainly in the inner part of the thighs, a small frontal white mark, and almost black head, fore and hind paws, and limbs (Coimbra-Filho 1985).

In 1976, Wasting Marmoset Syndrome (WMS) was reported for the first time as a disease with high morbidity and mortality (Sá 1999). That syndrome is characterized by clinical alterations, such as progressive emaciation, muscle atrophy, paralysis of the hind limbs, alopecia of the tail, nephritis, and intermittent diarrhea. It affects animals kept in captivity, which has been associated with immunologic reactions and components of the diet (Leite 2002). Nevertheless, WMS is not recognized as one specific syndrome or disease due to the great variety of factors that may influence its onset (Potkay 1992). Shimwell et al. (1979) and Murgatroyd \& Chalmers (1980) reported no hereditary influence.

Regarding food, the Callitrichidae are considered a very demanding species. Several food formulations have been proposed for the captivity by Coimbra-Filho \& Maia (1977), Coimbra-Filho et al. (1981), Clapp \& Tardif (1985), Tardif et al. (1988), and Barnard et al. (1988), aiming at the species' good growth, reproduction, and longevity. In addition, such formulations improve their capacity to resist to pathogenic agents and stress (Knapka et al. 1995, Oftedal \& Allen 1996, Wormell 2000).

Other studies correlate the appearance of WMS with gastrointestinal diseases (Chalifoux et al. 1982, Lewis et al. 1987), glucose intolerance (McNees et al. 1983) or primary deficiency of antioxidants (Gutteridge et al. 1986), parasitosis of the pancreatic ducts (Trichospirura leptostoma) (Pfister et al. 1990, Pissinatti et al. 1985), and other pathologies (lalegio \& Backer 1995).

\section{MATERIALS AND METHODS}

\section{Samples}

Sampling for this study comprised 12 hearts of Wied's blacktufted-ear marmoset (Callithrix kuhlii), 6 of which belonged to animals that died due to complications of WMS, such as marked cachexia, caused by intermittent diarrhea, and also limb paralysis, which make the survival of the animals difficult. The other 6 animals died due to different causes that did not affect the cardiomyocytes, such as fights within the animals' enclosures and intense intestinal parasitosis. Those animals originated from the Center of Primatology of Rio de Janeiro (Centro de Primatologia do Rio de Janeiro, CPRJ-FEEMA) and were kept in outdoor enclosures, thereby being exposed to the natural conditions of the Atlantic Forest. Three walls of the enclosures were made of wire mesh, and the fourth was made of concrete to provide protection and avoid visual contact with other animals in the colony, reducing stress.

Food and water were provided twice daily, and the diet consisted basically of bread, banana, egg, seeds, meat, dietary supplements, and Tenebrio molitor larvae. Both the healthy and affected animals lived under those same management conditions.

After died in the colony, the animals underwent necropsy, were classified and became part of the collection of the Museum of Primatology of the CPRJ-FEEMA, (Coimbra-Filho et al. 1986). Their hearts were immediately weighed, dissected, and fixed in $10 \%$ formalin solution (pH 7.2). This study was approved by the Ethical Committee (CETA, Plínio Leite University Center - UNIPLI) and received the protocol number $001 / 04$, although no animal was sacrificed. Several myocardial fragments were obtained, sent to the histology laboratory of the School of Veterinary Medicine (UNIPLI, Itaboraí, RJ), and were processed according to the method "orthotrip", because the cardiac muscle is an anisotropic tissue. This procedure allowed randomization, and anisotropic sections were obtained (Matfeld et. al. 1985).

The myocardial fragments were then embedded in paraffin, sectioned at 5ìm, and stained with Hematoxylin and Eosin (HE).

\section{Stereology and statistical analysis}

The stereological studies were carried out at the Morphology Laboratory of the Institute of Biosciences, (Unigranrio, Duque de Caxias, RJ).

Fifteen random fields were counted for each specimen, according to the M42 testing system, which was superimposed over the computer screen coupled to a photomicroscope. The M42 testing system consists of 21 line segments and 42 points in a testing area of $36.36 \mathrm{~d}^{2}$ (Weibel 1979, Weibel et al. 1966). (Fig.1)

For the purpose of stereological quantification, the myocardium was considered as consisting of cardiomyocytes and cardiac interstitium. The volume density $\left(\mathrm{V}_{\mathrm{v}}\right)$ was determined by points of the testing system lying above those structures, as long as they did not intercept the forbidden line or its extensions (Gundersen 1977, Matfeld et al. 1985). The $V_{V}$ myocyte included the cardiomyocyte and its nucleus. The $V_{V}$ vessels included the profile of vessels, and the $V_{V}$ connective included the connective tissue and cells other than myocytes and nerves (Weibel 1979).

The volume densities $\left(\mathrm{V}_{\mathrm{v}}\right)$ of myocytes, vessels, and connective tissue were calculated as follows:

\section{Where $P_{P}$ is the number of points lying above $\%$ structure, and $P_{T}$ is the total number of points of the testing system (in this case, 42 points).}

The numeric densities per area of the cardiomyocytic nucleus $\left(\mathrm{Q}_{\mathrm{A}[\mathrm{n}]}\right)$ and vessels $\left(\mathrm{Q}_{\mathrm{A}[\mathrm{v}]}\right)$ were calculated as follows:

$$
Q_{A}=\frac{N}{A_{T}} \quad \begin{aligned}
& \mathrm{L} / \mu \mathrm{m}^{2}, \text { where } \mathrm{A}_{\mathrm{T}} \text { is the testing area equivalent to } \\
& 36.36 \mathrm{~d}^{2} \text { in the } \mathrm{M}_{42} \text { testing system. }
\end{aligned}
$$

The length density of vessels $\left(\mathrm{L}_{\mathrm{v}}[\mathrm{v}]\right)$ was calculated as follows:

$$
L v=2 Q_{A} \quad \mu \mathrm{m} / \mu \mathrm{m}^{3}
$$

The surface density of cardiomyocytes $\left(\mathrm{S}_{\mathrm{v}}[\mathrm{m}]\right)$ and vessels $\left(\mathrm{S}_{\mathrm{v}}[\mathrm{v}]\right)$ was determined as follows:

$$
S v=\frac{2 . I}{L_{T}} \quad \begin{aligned}
& \mu \mathrm{m}^{2} / \mu \mathrm{m}^{3}, \text { where I is the intersection of the myo- } \\
& \text { cardial components with the testing line, and } \mathrm{L}_{\mathrm{T}} \\
& \text { is the length of the testing line (21.d in the } \mathrm{M}_{42} \\
& \text { testing system). }
\end{aligned}
$$


The statistical differences between healthy and affected animals were tested by use of the Mann-Whitney $U$-test (á = 0.05) (Zar 1999).

\section{RESULTS}

The results are shown in Tables 1 and 2 and Figures 2 to 5. Callithrix kuhlii, as other primates, has a structure in the myocardium that is very common in mammals, a bundle of myocytes separated by an interstitium of connective tissue. In animals affected by WMS (Fig.3), a greater amount of interstitium among myocytes may be qualitatively observed when compared with that of healthy individuals (Fig.2).

Regarding the biometry performed in the animals, body weight was $63.43 \%$ lower in those affected by WMS, and a statistically significant difference was observed between the mean weights in healthy and affected animals $(P=0.003)$. (Table 1)

The cardiac weight in the animals affected by WMS was $65.7 \%$ smaller than that in the healthy animals, and their mean values also differed significantly $(P=0.016)$.

Considering the stereological parameters, the $Q_{A}$ nucleus values in the affected animals were approximately $5.0 \%$ smaller than those in the healthy animals. The $Q_{A}$ vessel values, however, were $5.5 \%$ greater in the affected animals, although they were not statistically confirmed (Table 2).

The $\mathrm{V}_{\mathrm{V}}$ myocyte values of the Callithrix kuhlii studied are

\section{Table 1. Descriptive statistics and comparisons of the biometric parameters studied in Callithrix kuhlii healthy and affected by Wasting Marmoset Syndrome (WMS)}

\begin{tabular}{ccccc}
\hline $\begin{array}{c}\text { Biometric } \\
\text { parameters }\end{array}$ & Healthy & Affected & $\begin{array}{c}\text { Mann-Whitney } \\
\text { U-test }\end{array}$ & $\begin{array}{c}\text { Significance } \\
\text { p }\end{array}$ \\
\hline $\begin{array}{c}\text { Body weight } \\
\text { (grams) }\end{array}$ & $405.67 \pm 72.82$ & $257.33 \pm 26.33$ & 0.001 & 0.003 \\
$\begin{array}{c}\text { Cardiac weight } \\
\text { (grams) } \\
\text { Age } \\
\text { (grams) }\end{array}$ & $2.77 \pm 0.62$ & $1.82 \pm 0.55$ & 3.000 & 0.016 \\
& $4.0 \pm 3.48$ & $5.58 \pm 2.54$ & 12.50 & 0.378
\end{tabular}

Table 2. Descriptive statistics and comparisons of the cardiac parameters studied in Callithrix kuhlii healthy and affected by Wasting Marmoset Syndrome (WMS)

\begin{tabular}{|c|c|c|c|c|}
\hline $\begin{array}{l}\text { Biometric } \\
\text { parameters }\end{array}$ & Healthy & Affected & $\begin{array}{c}\text { Mann-Whitney } \\
\text { U-test }\end{array}$ & $\begin{array}{c}\text { Significance } \\
\mathrm{p}\end{array}$ \\
\hline $\begin{array}{c}\mathrm{Q}_{\mathrm{A}} \text { nucleus } \\
\left(1 / \mu \mathrm{m}^{2}\right)\end{array}$ & $64.30 \pm 25.57$ & $61.16 \pm 15.13$ & 16.00 & 0.748 \\
\hline $\begin{array}{l}\mathrm{Q}_{\mathrm{A}} \text { vessel } \\
\left(1 / \mu \mathrm{m}^{2}\right)\end{array}$ & $29.15 \pm 16.30$ & $30.86 \pm 10.95$ & 13.50 & 0.470 \\
\hline $\begin{array}{l}\mathrm{V}_{\mathrm{V}} \text { vessel } \\
\text { (\%) }\end{array}$ & $1.0 \pm 0.5$ & $0.5 \pm 0.2$ & 5.00 & 0.034 \\
\hline $\begin{array}{l}\mathrm{V}_{\mathrm{V}} \text { connective } \\
\text { tissue (\%) }\end{array}$ & $30.8 \pm 5.8$ & $33.5 \pm 5.0$ & 13.00 & 0.423 \\
\hline $\mathrm{V}_{\mathrm{V}}$ myocyte & $68.2 \pm 5.2$ & $66.0 \pm 5.1$ & 15.00 & 0.630 \\
\hline $\begin{array}{l}\mathrm{S}_{\mathrm{V}} \text { nucleus } \\
\left(\mu \mathrm{m}^{2} / \mu \mathrm{m}^{3}\right)\end{array}$ & $3.49 \pm 2.35$ & $3.49 \pm 1.05$ & 16.50 & 0.809 \\
\hline $\begin{array}{c}S_{V} \text { vessel } \\
\left(\mu \mathrm{m}^{2} / \mu \mathrm{m}^{3}\right)\end{array}$ & $2.07 \pm 1.21$ & $1.46 \pm 0.96$ & 12.00 & 0.334 \\
\hline $\begin{array}{c}\mathrm{L}_{\mathrm{V}} \text { vessel } \\
\left(\mu \mathrm{m}^{2} / \mu \mathrm{m}^{3}\right)\end{array}$ & $58.30 \pm 32.61$ & $61.73 \pm 21.91$ & 13.50 & 0.470 \\
\hline
\end{tabular}

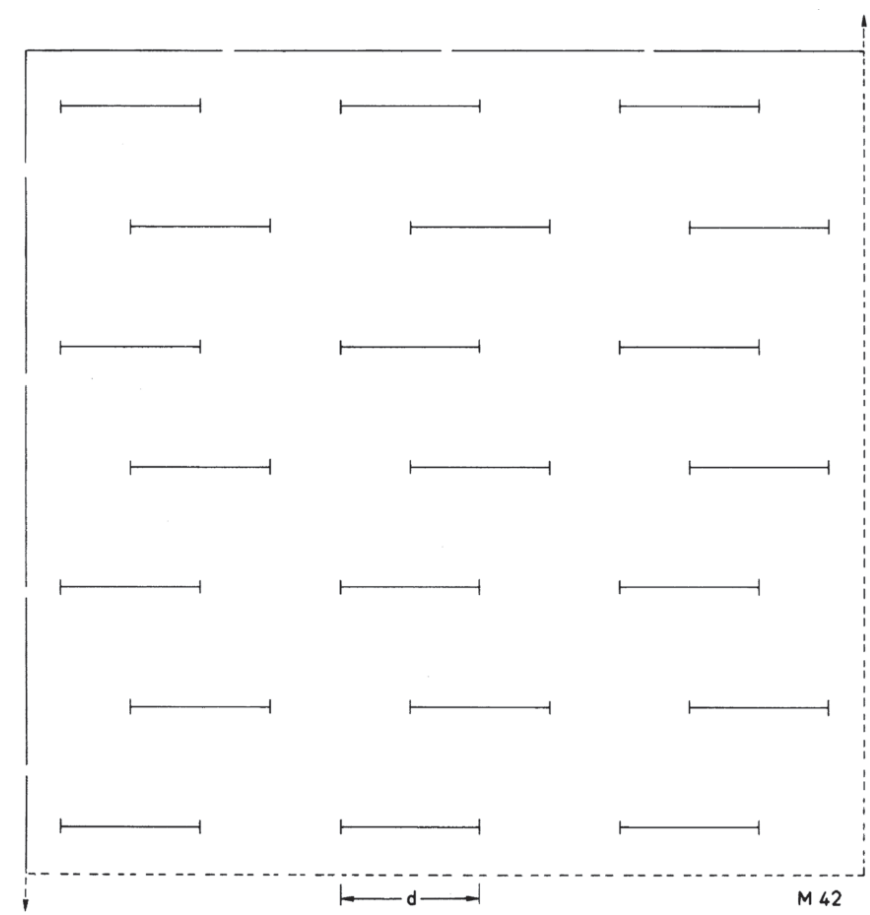

Fig.1.Diagram of the M42 testing system incorporating the forbidden line (dotted line). The elements intercepted by that line should not be considered to avoid the bias of over estimation (Gundersen 1977).

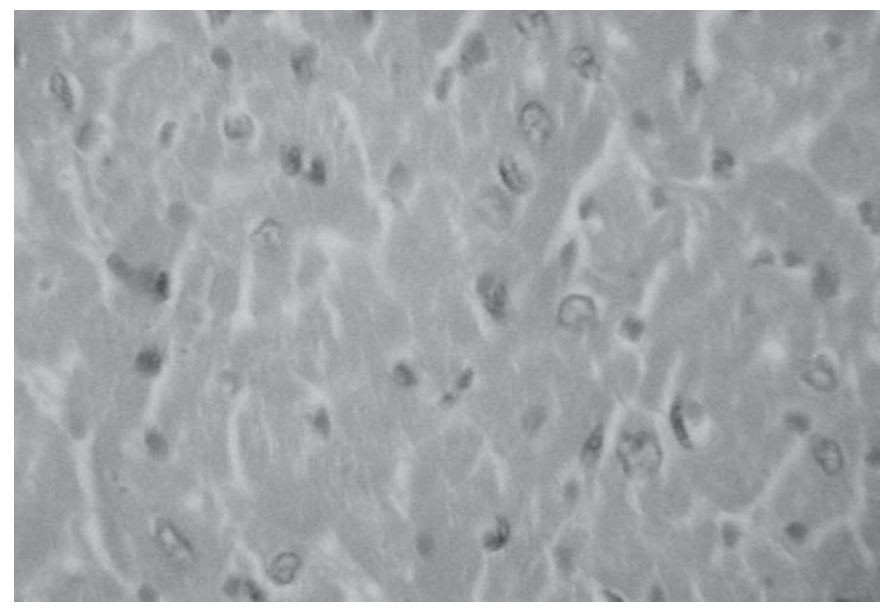

Fig.2. Heart muscle of a healthy Callithrix kuhlii. HE, obj.40.

shown in Figures 4 and 5 . The volume density of the myocyte, $\mathrm{V}_{\mathrm{V}}$ myocyte, was $2.2 \%$ smaller in the affected animals, and that of the connective tissue, $\mathrm{V}_{\mathrm{V}}$ connective, was $2.7 \%$ greater.

The volume density of the vessel, $\mathrm{V}_{\mathrm{V}}$ vessel, was $50 \%$ smaller in the animals affected by WMS (Table 1). According to the MannWhitney test, the $V_{v}$ vessel values were statistically significant when comparing healthy and affected animals (Table 2).

The $S_{V}$ nucleus values were exactly the same in both groups, while the $S_{V}$ vessel values were approximately 30\% smaller in affected animals. Those values, however, were not statistically confirmed (Table 2). The $\mathrm{L}_{\mathrm{V}}$ vessel value in the affected group was $3.43 \%$ greater than that in the healthy group. 


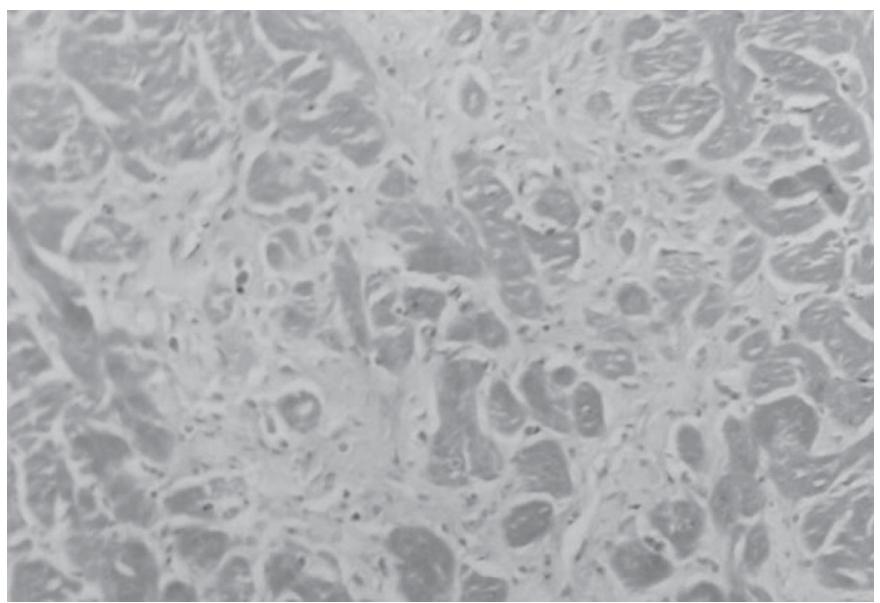

Fig.3. Heart muscle of by Wasting Marmoset Syndrome affected Callithrix kuhlii. HE, obj.20.

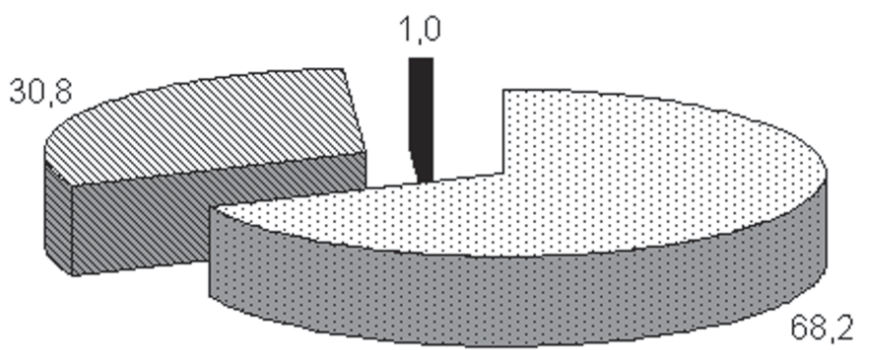

Fig.4. Graphs depicting the myocardial volume densities, $\mathrm{V}_{\mathrm{V}}(\%)$, for myocytes (dotted area), connective tissue (lined area), and vessels (solid color area) of the healthy animals.

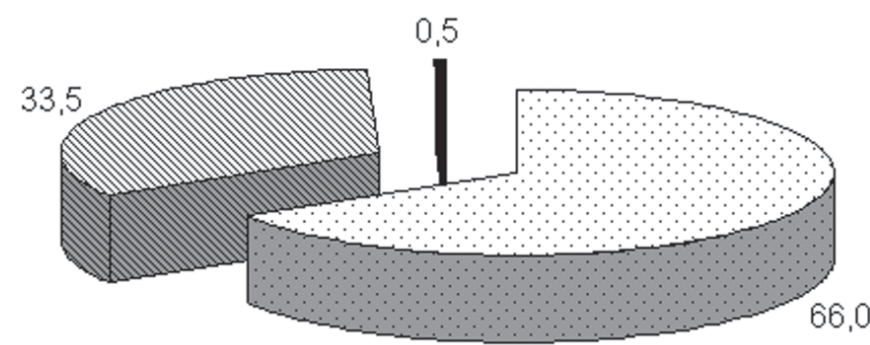

Fig.5. Graphs depicting the myocardial volume densities, $\mathrm{V}_{\mathrm{v}}(\%)$, for myocytes (dotted area), connective tissue (lined area), and vessels (solid color area) of by the Wasting Marmoset Syndrome (WMS) affected animals.

\section{DISCUSSION}

The relation between cardiac and body weights may not be a significant factor in WMS; however, the presence of cardiac interstitial fibrosis may render the heart vulnerable to ischemia.

The necropsy findings and microscopic confirmation of structural alterations, in several organs, even slight to moderate, contribute to the reduction in the metabolic efficiency in the affected primates.

Although the etiology of WMS is unknown, most changes in that disease have been attributed to protein malnutrition and muscle loss, which, according to Logan \& Kanwar (1996) and Barnard et al. (1988), may be reverted with nutritional intervention. The size of the muscle fibers vary on the age and diet of the animals; therefore, in animals affected by WMS, inappropriate ingestion of nutrients and amino acids occurs, resulting in muscle dystrophy and inhibition of muscle growth (Gurtler et al. 1987). In regard to biometry, the differences in body weight, cardiac weight, and $V_{v}$ vessel were statistically significant, confirming the muscle mass loss in affected animals. That syndrome is known to cause exacerbated weight loss. According to our findings, a decrease in the volume density of the vessels occurs, which we suppose may result in a decreased blood flow to the myocardium and consequent general decrease in myocardial mass and metabolism of cardiac cells. Such biometric differences could not be related to differences in the animals' ages, because statistically significant differences were not detected by the Mann-Whitney test for the parameter "age".

Although not statistically confirmed ( $p>0.05)$, in animals affected by WMS, $Q_{A}$ showed a decrease in the number of nuclei per unit of area, as well as a lower volume density of myocytes $\left(\mathrm{V}_{\mathrm{V}}\right.$ myocyte). This means that the myocardium had a numerical and volumetric reduction in cardiomyocytes. Such numerical trend was found.

Stereology of the myocyte showed that animals with WMS had the same number of myocytes, whose sizes, however, were smaller than those in healthy animals. However, with the significance level adopted, those data were not confirmed.

Burity et al. (1996) studied the myocardium of Callithrix jacchus and $C$. penicillata, and the following $\mathrm{V}_{\mathrm{V}}$ values were established for the myocardium: $V_{V}$ myocyte $=68.6 \%$, and $V_{v}$ connective tissue $=31.45 \%$. These values are similar to those obtained in the present study for Callithrix kuhlii within the same group, the "Jacchus" group.

Pissinatti et al. (2003) studied the myocardium of 4 taxa of Leontopithecus (L. rosalia, L. chrysomelas, L. C. chrysopygus, and $L$. c. caissara), and reported that $\mathrm{V}_{\mathrm{V}}$ myocyte varied from 79.6 to 88.4 , while the $V_{V}$ connective tissue 10.2 to 17.4. These values are important for comparison with those of this study and are similar because the animals, although from different species, belong to the same family, Callitrichidae.

Rodrigues (2003) reported that dogs undergoing cardiac denervation, which causes physiological alterations, had an increase in $\mathrm{L}_{\mathrm{V}}$ vessel and a decrease in $\mathrm{V}_{\mathrm{V}}$ vessel, as compared with a group of dogs that did not undergo cardiac denervation. These alterations may be compared with those found in animals affected by WMS as compared with healthy animals.

Nowadays, this is the first study to correlate body mass loss and cardiac stereology in animals with WMS. Therefore, the inexistence of previous results makes the comparison with ours difficult.

In this study, morphometry (biometry and stereology) showed that WMS affects animals, including their myocardium, generating a significant reduction in body weight and cardiac weight, and a reduction in the volume density of vessels. Such facts, although difficult to understand, may be important in the differential diagnosis with other kinds of disease. Further studies are required. 


\section{CONCLUSIONS}

- Wasting marmoset syndrome caused body mass loss in affected animals. It also caused a decrease in the cardiac mass in affected animals and a significant decrease in the volume density of vessels in the myocardium.

- This condition may render the heart vulnerable to ischemia due to the metabolic decline of cardiac muscle cells.

Acknowledgements.- This study was supported by a grant from CNPq (Proc.52.41.14/97-0) and Faperj (Proc.170-873/00 and 171-573/00). We also thank the American Journal of Primatology, the Greater Los Angeles Association (GLAZA), and the American Zoological Association (AZA) for support the Centro de Primatologia do Rio de Janeiro (CPRJ- FEEMA). Also to Centro Universitário Plínio Leite (UNIPLI), Universidade do Grande Rio (UNIGRANRIO) and Centro de Primatologia do Rio de Janeiro (CPRJ-FEEMA) for the material and technical support.

\section{REFERENCES}

Barnard D., Knapka, J. \& Renquist D. 1988. The apparent reversal of wasting marmoset syndrome by nutritional intervention in Saguinus mystax. Lab. Anim. Sci. 38 (2):282-288.

Burity C.H.F., Mandarim-De-Lacerda C.A. \& Pissinatti A. 1996. Stereology of the myocardium in two species of Callithrix (Callitrichidae, Primates). Ann. Anat. 178(3):437-441.

Chalifoux L.V., Bronson R.T., Escajadillo A. \& McKenna S. 1982. An analysis of the association of gastroenteric lesions with chronic wasting syndrome of marmoset. Veter. Pathol. 19(2):141-162.

Clapp N.K. \& Tardif S.D. 1985. Marmoset husbandry and nutrition. Dig. Dis. \& Sci. 30(2):175-235.

Coimbra-Filho A.F. \& Maia A. 1977. A alimentação de sagüi em cativeiro. Brasil Florestal 29(1):15-26.

Coimbra-Filho A.F., Silva R.R. \& Pissinatti A. 1981. Sobre a dieta de Callitrichidae em cativeiro. Revta Biot. 1(1):83-93.

Coimbra-Filho A.F. 1985. Espécies ameaçadas em extinção. FBCN 9:4.

Coimbra-Filho A.F., Pissinatti A. \& Silva R.R. 1986. O acervo do Museu de Primatologia, (CPRJ-FEEMA), p.505-514. In: Melo M.T. (ed.), A Primatologia no Brasil $2^{\underline{a}}$ ed. Sociedade Brasileira de Primatologia, Belo Horizonte, Minas Gerais.

Gundersen H.J.G. 1977. Notes on the estimation of the numerical density of arbitrary profiles: the edge effect. J. Microsc.111(2):219-227.

Gurtler H., Ketz H.A., Kolb E., Schroder L. \& Seidel H. 1987. Sistema locomotor, p.147-160. In: Gurtler H., Ketz H.A., Kolb E., Schroder L. \& Seidel H. (ed.), Fisiologia Veterinária, Guanabara Koogan, Rio de Janeiro.

Gutteridge J.M.C, Taffs L.F., Hawkey C.M. \& Rice-Evans C. 1986. Susceptibility of tamarins (Saguinus labiatus) red blood cell membrane lipids to oxidative stress implications for wasting marmoset syndrome. Lab. Animal. 20(1):40147.

Haig D. 1999. What is a Marmoset? Am. J. Primatol. 4(1):285-296.

Ialegio M. \& Baker A.J. 1995. Results of a preliminary survey into wasting marmoset syndrome in Callitrichid collections, p.148-158. Proceedings of the First Annual Conference of the National Advisory Group of the American Zoo \& Aquarium Association, New York.

Kapka J.J., Barnard D.E., Bayne K.A.L., Lewis S.M., Marriott B.M. \& Oftedal O. 1995. Nutrition, p.211-248. In: Bennett B.T., Abee C.R. \& Henrickson R. (ed.), Nonhuman Primates in Biomedical Research: biology and management. Academic Press, San Diego.

Leite M.C.P. 2002. Patologia comparada de Callithrix geoffroyi Humboldt, 1982 (Callitrichidae, Primates) mantidos em cativeiro no Centro de Primatologia do Rio de Janeiro, Master Dissertation, Universidade de São Paulo, São Paulo. 194p.

Lewis D.H., Stein FJ. \& Mc Murray D.N. 1987. Fecal microflora of marmoset with wasting marmoset syndrome. Lab. Anim. Sci. 37(2):103-105.

Logan A.C. \& Kanwar N.M.K. 1996. Clinical Pathology changes in two Marmosets with Wasting Marmoset Syndrome. Lab. Anim. Pathol. 6(4):707709.

Matfeldt T., Mobius H.J. \& Mall G. 1985. Orthogonal triplet probes: an efficient method for unbiased estimation of length and surface of objects with unknown orientation in space. J. Microsc. 139(3): 279-289.

Mc Nees D.W., Lewis R.W., Ponzio B.J., Stein F.J. \& Sis R.F. 1983. Carbohydrate tolerance serumalbumin and protein values of normal and "waster" marmosets (Callithrix jacchus). Primates 24(3):537-545.

Murgatroyd, L.B., Chalmers, D.T. 1980. A histological and histochemical study of normal and diseaed muscle in marmosets Callithrix jacchus. J. Comp. Pathol. 90(3):373-378.

Oftedal O.T. \& Allen M.E. 1996. The feeding and nutrition of omnivores with emphasis on primates, p.148-156. In: Kleiman, D.G. (ed.), In capitivity: principles and techiniques. Chicago Press, Chicago.

Pfister R., Heider K., Ilegen B. \& Belinger R. 1990. Trichospirura leptostoma: a possible cause of wasting disease in the marmoset Zschr Versuchstierk 33(2):157-161.

Pissinatti A., Tortelly R., Coimbra-Filho A. F. \& Cruz J.B. 1985. Alterações causadas por Trichospirura leptostoma em pâncreas de Leontopithecus chrysopygus (Mikan, 1823)- Callitrichidae- Primates. Rev. Bras. Méd. Vet. 7(6):184-185.

Pissinatti A., Burity C.H.F. \& Mandarim-De-Lacerda C.A. 2003. Stereology of the myocardium in Leontopithecus (Lesson, 1840) Callitrichidae- Primates. J. Med. Primatol. 32(1):1-9.

Potkay S. 1992. Diseases of the Callitrichidae: a review. J. Med. Primatol. 21(3):189-236.

Rylands AB., Coimbra-Filho A.F. \& Mittermeier R.A. 1993. Marmosets. p.1177. In: Rylands A.B., Coimbra-Filho A.F. \& Mittermeier (ed.), Marmosets and Tamarins Systematics, Behaviour, and Ecology. Oxford University Press, Oxford.

Rodrigues M.R. 2003. Alterações morfológicas em corações denervados de cães, marca-passo vs. miocárdio atrial, estudo estereológico. Doctor Dissertation, Universidade Federal Rural do Rio de Janeiro, Seropédica, RJ. 54p.

Sá L.R.M. 1999. Determinação e caracterização de enfermidades que acometem calitriquideos e cebídeos. Master Dissertation, Universidade de São Paulo, São Paulo, SP. 174p.

Shimwell M., Warrington B.F. \& Fowler J.S.L. 1979. Dietary habits relating to "wasting marmoset syndrome" (WMS). Lab. Anim. 13(2):139-142.

Tardif S.D., Clapp N.K., Henke M.A., Carson R.L. \& Knapka J.J. 1988. Maintenance of cotton-top tamarins fed an experimental pelleted diet versus a highy diverse seulltened diet. Lab. Anim. Sci. 38(4):588-591.

Weibel E.R., Kistler G.S. \& Scherle W.F. 1966. Practical for morphometric cytology. J. Cell Biol. 30(1):23-28.

Weibel E.R. 1979. Stereological Methods. Practical Methods for Biological Morphometry. Academic Press, New York, NY. 415p.

Wormell D. 2000. Management and guideline for Pied Tamarins Saguinus bicolor bicolor. DODO 36:87.

Zar H. 1999. Biostatistical Analysis. Prentice Hall, Englewood Cliffs. 718p. 